\title{
Effect of sex on feed intake, growth and nutrients digestibility in Blackhead sheep fed complete mash rations of crop residues
}

\author{
E.M. Aregheore* \\ Department of Animal Science, School of Agricultural Sciences, \\ University of Zambia \\ Great East Road Campus, Lusaka, Zambia
}

(Received 23 November 1996; accepted 6 February 1997)

\begin{abstract}
Three complete mash rations formulated with crop residues: groundnut sheil (GNS), sunflower heads (SFII) and citrus pulp waste (CPW) were tested using 18, 10-month-old Blackhead sheep ( 9 ram lambs and 9 ewe lambs) of initial body weight $16.9 \pm 0.59 \mathrm{~kg}$ in a $2 \times 3$ factorial randomized complete design. The three rations contained about $13 \% \mathrm{CP}$ and the parameters tested were feed intake, growth and nutrients digestibility. Sex had no effect $(P>0.05)$ on feed intake of the sheep in any of the rations offered. Final average body wcight among sheep in the three rations were not significantly $(\mathrm{P}>0.05)$ different from each other, however, within treatments sex had an effect $(\mathrm{P}<0.05)$ on final average body weight. Ram lambs had higher $(\mathrm{P}<0.05)$ final average body weight than ewes. This was also the case in average daily live weight gains. Among the three rations, rams and ewes on the CPW ration had better $(\mathrm{P}<0.05)$ growth rates than those on GNS and SFII. Feed efficiency ( $\mathrm{kg} \mathrm{DMI} / \mathrm{kg}$ live weight gain) followed the pattern of growth rate. Nutrients were better $(\mathrm{P}<0.05)$ digested by ram lambs than by ewe lambs of the three rations of fered. Nutrients digestion was, however, better $(P<0.05)$ in ram and ewe lambs fed the CPW ration.
\end{abstract}

KEY WORDS: feed intake, growth, digestibility, crop residues, shecp, sex

\footnotetext{
* Present address for correspondence: Institute for Animal Production in the Tropics and Subtropics 480, Hohenhein University, D-70593 Stuttgart, Germany.

Permanent Address: Department of Agricultural Sciences, Animal Production Unit, College of Education, P.M.B. 1251, Warri, Delta State, Nigeria
} 


\section{INTRODUCTION}

The integration of small ruminant production with crop residues remains underappreciated and unexplored among small holder farmers in Zambia (Aregheore, 1994a). Crop residues are a key element in tropical ruminant nutrition (deHaan, 1991), and can meet the nutritional requirements of animals if properly processed. The major draw back in the use of crop residues lies in their low feeding value due to their high fibre and low protein content (Sharma and Rajora, 1971; deHaan, 1991; Aregheore and Chimwano, 1992; Aregheore, 1994b).

However, their importance in ruminant nutrition has been stressed in temperate and tropical countries (Rakes, 1969; Cappock et. al.,1974; Reddy and Reddy, 1981, 1983; Krishnamohan and Charyule, 1983; deHaan, 1991; Ikhatua et. al. 1991; Aregheore, 1994a,b, 1996). The use of crop residues in complete rations has been reported (Rakes 1969; Reddy and Reddy, 1981; Kawalker and Patel, 1978; Aregheore, 1992). Using crop residues in compounding complete rations facilitates total feed intake of all portions of the ration offered, rapid growth of animals so they reach market weight earlier than conventional grazing animals, without supplementary feeding. Rakes (1969) reported that the incorporation of crop residues in balanced complete rations provides uniform consumption to meet daily nutrient requirements of ruminant livestock. This minimizes labour, reduces wastage and optimizes the utilization of waste materiais (Reddy and Reddy, 1983; Aregheore, 1992; Aregheore et. al., 1996).

The aim of this experiment was to investigate the effect of the sex of Blackhead sheep in the utilization of complete rations based on crop residues in Zambia.

\section{MATERIAL AND METHODS}

Groundnut shells (GNS), sunflower head (SFH) and citrus pulp waste (CPM) were obtained from different areas within Lusaka, Zambia. They were sun-dried to a constant weight and then ground through a $6 \mathrm{~mm}$ sieve hammer mill (Turner and Metals, Lusaka). They were later moistened to contain $60 \% \mathrm{DM}$, maintained at $21^{\circ} \mathrm{C}$ for at least 10 days and aerated for $24 \mathrm{~h}$ before being used in the preparation of rations. Other ingredients used were maize grain, maize bran, urea $(46 \% \mathrm{~N})$, common salt and mineral + vitamin premix. The feedstuffs were compounded into three rations (mash) to represent each of the crop residues (Tables 1 and 2). The rations were isonitrogenous. 
TABLE 1

Chemical composition of the three crop residues

\begin{tabular}{lccc}
\hline & \multicolumn{3}{c}{ Crop residues } \\
\cline { 2 - 4 } Nutrients, \% & groundnut shells & sunflower heads & citrus pulp waste \\
\hline Dry matter & 89.88 & 90.39 & 89.00 \\
Crude protein & 7.96 & 8.98 & 7.60 \\
Ash & 10.09 & 9.63 & 8.46 \\
Ether extract & 1.92 & 2.54 & 1.45 \\
NDF & 63.72 & 72.00 & 59.70 \\
ADF & 42.63 & 46.10 & 38.68 \\
ADL & 14.60 & 18.31 & 12.78 \\
Hemicellulose & 24.09 & 25.90 & 21.02 \\
Cellulose & 38.09 & 37.42 & 34.36 \\
GE MJ kg- ${ }^{-1}$ DM & 17.78 & 18.20 & 16.10 \\
\hline
\end{tabular}

TABLE 2

Ingredients and composition of the complete rations, air dry basis, $\%$

\begin{tabular}{lccc}
\hline & \multicolumn{3}{c}{ Rations } \\
\cline { 2 - 4 } Ingredients & groundnut shells & sunflower heads & citrus pulp waste \\
\hline Maize & 15.50 & 15.50 & 15.50 \\
Maize bran & 36.10 & 36.10 & 36.10 \\
Groundnut shells & 45.00 & 0.00 & 0.00 \\
Sunflower heads & 0.00 & 45.00 & 0.00 \\
Citrus pulp waste & 0.00 & 0.00 & 45.00 \\
Urea (46\% N) & 2.40 & 2.40 & 2.40 \\
Mineral-vitamin mixture & 0.50 & 0.50 & 0.50 \\
Salt & 0.50 & 0.50 & 0.50 \\
\hline
\end{tabular}

* mineral-vitamin mix provided the following $500000 \mathrm{IU}$ vit. A, $125000 \mathrm{JU}$ vit. $\mathrm{D}_{3}, 1330 \mathrm{mg}$ Co, 250 $\mathrm{g} \mathrm{Ca}, 2257 \mathrm{mg} \mathrm{Cu}, 41730 \mathrm{mg} \mathrm{Fe}, 4418 \mathrm{mg} \mathrm{Mn}, 38220 \mathrm{mg} \mathrm{Zn}$ and $113400 \mathrm{mg} \mathrm{Mg}$

Eighteen Blackhead sheep ( 9 rams and 9 ewes) were used. The sheep were about ten months old with an average initial body weight of $16.9 \pm 0.59 \mathrm{~kg}$, and were divided into three groups according to sex so that there were 3 rams and 3 cwes in each treatment. The experiment was a $2 \times 3$ factorial randomized complete design. The sheep were housed and fed in groups of three, and for each ration there were two group pens. Thus there was a total of six group-pens. The sheep were fed twice daily at 8.00 and $18.00 \mathrm{~h}$, and were allowed free access to fresh clean water. The rations offered were either increased or decreased depending on intake. Average weight at the beginning and at the end of the trial was used to express growth rate and voluntary dry matter intake. 
At the end of the growth phase, the sheep were housed individually for digestibility studies. Faeces voided by each sheep during the day were collected and sampled for 7 days using the total faecal collection method. At the end faeces were dried in a forced draught oven at $70^{\circ} \mathrm{C}$ for $24 \mathrm{~h}$. The faeces for each sheep were bulked and $25 \%$ of the total sample was taken, milled and kept in air tight bottles until chemical analysis. The rations fed were also sampled for approximate chemical analysis.

\section{Analytical methods}

Approximate chemical analyses of crop residues, rations (Table 3) and faeces were according to the outlined procedures of AOAC (1980). Gross energy values were determined by the ballistic bomb calorimeter using benzoic acid as the standard. Fibre fractions, NDF, ADF and ADL, hemicellulose and cellulose were analyzed using the procedures of Goering and Van Soest (1970).

Analysis of variance for factorial randomized complete design Steel and Torrie (1980) was used to analyze data. Significant differences between means were compared using Bonferroni t-statistics (Gill, 1978). All data between the sexes within treatments were subjected to the Student t-test.

TABLE 3

Proximate composition of the rations, DM basis

\begin{tabular}{lccc}
\hline & \multicolumn{3}{c}{ Rations } \\
\cline { 2 - 4 } Nutrients, \% & groundnut shells & sunflower heads & citrus pulp waste \\
\hline Dry matter & 90.89 & 91.30 & 90.54 \\
Crude protein & 13.10 & 13.30 & 12.90 \\
Total ash & 3.70 & 4.10 & 3.60 \\
Ether extract & 5.40 & 5.70 & 6.10 \\
NDF & 46.49 & 49.40 & 42.68 \\
ADF & 29.27 & 31.30 & 26.89 \\
ADL & 6.85 & 7.24 & 5.96 \\
Hemicellulose & 17.22 & 18.10 & 15.79 \\
Ccllulose & 26.12 & 28.16 & 24.53 \\
GE MJ/kg & 16.25 & 16.98 & 16.16 \\
\hline
\end{tabular}

\section{RESULTS AND DISCUSSION}

Data on body weight, dry matter intake and feed efficiency are presented in Table 4. There was no significant difference $(P>0.05)$ among sheep in final average body weight, but within treatments there were significant differences 
TABLE 4

Weight gain, dry matter intake and feed efficiency of Blackhead sheep fed the three complete mash ration (40 days)

\begin{tabular}{|c|c|c|c|}
\hline \multirow{2}{*}{ Parameters } & \multicolumn{3}{|c|}{ Rations } \\
\hline & groundnut shells & sunflower heads & citrus pulp waste \\
\hline \multicolumn{4}{|c|}{ Initial average $\mathrm{LW}, \mathrm{kg}$} \\
\hline ram lambs & $16.9 \pm 0.82$ & $16.9 \pm 0.80$ & $16.9 \pm 0.14$ \\
\hline ewe lambs & $15.8 \pm 0.32$ & $15.6 \pm 0.70$ & $15.8 \pm 0.15$ \\
\hline mean & $16.4 \pm 0.57$ & $16.3 \pm 0.75$ & $16.4 \pm 0.14$ \\
\hline \multicolumn{4}{|c|}{ Final average $\mathrm{LW}, \mathrm{kg}$} \\
\hline ram lambs & $23.8 \pm 1.03^{\mathrm{a}}$ & $24.3 \pm 0.98^{\mathrm{a}}$ & $25.6 \pm 0.62^{\mathrm{a}}$ \\
\hline ewe lambs & $20.9 \pm 0.92^{b}$ & $21.0 \pm 1.00^{\mathrm{h}}$ & $22.2 \pm 0.50^{\mathrm{b}}$ \\
\hline mean & $22.3 \pm 0.98$ & $22.7 \pm 0.99$ & $23.9 \pm 0.56$ \\
\hline \multicolumn{4}{|c|}{ Live weight gain, $\mathrm{kg}$} \\
\hline ram lambs & $6.9 \pm 0.21^{1}$ & $7.4 \pm 0.18^{\mathrm{a} 12}$ & $8.7 \pm 0.48^{\mathrm{a} 1}$ \\
\hline ewe lambs & $5.0 \pm 0.60$ & $5.4 \pm 0.30^{\mathrm{b}}$ & $6.3 \pm 0.35^{b}$ \\
\hline mean & $6.0 \pm 0.41$ & $6.4 \pm 0.24$ & $7.5 \pm 0.42$ \\
\hline \multicolumn{4}{|c|}{ Average daily gain, g/d } \\
\hline ram lambs & $0.174^{\mathrm{a}}$ & $0.186^{\mathrm{a}}$ & $0.218^{\mathrm{a}}$ \\
\hline ewe lambs & $0.127^{\mathrm{b}}$ & $0.136^{\mathrm{b}}$ & $0.158^{\mathrm{b}}$ \\
\hline mean & $0.151^{1}$ & $0.161^{12}$ & $0.188^{2}$ \\
\hline \multicolumn{4}{|l|}{ Average DMI } \\
\hline ram lambs & $1.0 \pm 0.06$ & $1.0 \pm 0.04$ & $1.0 \pm 0.07$ \\
\hline ewe lambs & $1.0 \pm 0.08$ & $1.0 \pm 0.06$ & $1.0 \pm 0.06$ \\
\hline mean & $1.0 \pm 0.07$ & $1.0 \pm 0.05$ & $1.0 \pm 0.07$ \\
\hline \multicolumn{4}{|c|}{ Feed efficiency, } \\
\hline \multicolumn{4}{|c|}{$\mathrm{kg} \mathrm{DMI} / \mathrm{kg} \mathrm{LW}$ gain } \\
\hline ram lambs & $5.97^{\mathrm{a}}$ & $5.59^{\mathrm{a}}$ & $4.72^{\mathrm{a}}$ \\
\hline ewe lambs & $8.03^{\mathrm{bl}}$ & $7.57^{\mathrm{bl2}}$ & $6.52^{\mathrm{b} 2}$ \\
\hline mean & 7.00 & 6.58 & 5.62 \\
\hline
\end{tabular}

$a, b, c-$ means within each treatment for each variable of different superscript differ at $\mathrm{P}<0.05$ 1, 2, 3 - means within row with different superscript differ at $\mathrm{P}<0.05$

$(\mathrm{P}<0.05)$ between rams and ewes. The ewes had lower $(\mathrm{P}<0.05)$ growth rates than the rams. Also, the growth rate of rams and ewes was better $(\mathrm{P}<0.05)$ in the CPW than in SFH and GNC, however, within the CPW ration rams also had better growth rates than ewes $(P<0.05)$. Shelton and Carpenter $(1972)$ reported that male animals usually have higher gains than females. With sheep, Abouheif et al. (1992) reported higher growth rate for Najdi ram lambs than ewe lambs of the same age. Also, Aregheore (1994b) reported higher growth rate for rams than 
ewes of the West African Dwarf goats in Southern Nigeria where course forage was fed in the dry season.

Feed intake did not differ between rams and ewes, or treatments $(P>0.05)$. Results of growth rate and dry matter intake indicated that even when DMI is at the same level between ewes and rams, rams still gained better. This, therefore, confirmed earlier reports that male animals grow better than females of the same age even when they are fed the same ration and/or are subjected to the same environmental conditions (Aregheore, 1994b).

Voluntary DMI were within the same level, even though the fibre fractions of the rations differed. The processing (grinding) of the residues before their incorporation with other ingredients to give the final complete feed mash helped the sheep consume every portion of the rations offered. Due to the even distributions of nutrients in the rations, the sheep could not give preference to a particular portion. Sheep generally are selective in nature, preferring nonfibrous feedstuffs (Leng, 1981; Aregheore, 1996), however, the total mixture made it impossible for them to differentiate the fibrous and non-fibrous portions of the rations offered. The preparation improved the utilization of agricultural wastes and also improved DMI of the rations. The results obtained in improved feed intake are in agreement with Leng et al. (1955), Kawalker and Patle (1978), Reddy and Reddy, (1983), Aregheore et al.(1995). These results are a step forward in matching ruminant livestock production with locally available feed resources in Zambia, a land-locked country. Feed efficiency (kg DMI/kg live weight gain) was influenced by growth rate, thus the rams had better $(\mathrm{P}<0.05)$ feed efficiency than the ewes. Among the rations, the sheep on the CPW ration had better $(\mathrm{P}<0.05)$ feed efficiency than the others, however, there was no difference between GNS and SFH fed sheep. Aregheore (1994b) with goats observed a similar trend in feed efficiency, where the bucks were better than the female goats.

Nutrients digestibility (Table 5) was on average better in the rams than in the ewes in all the rations offered. With the exception of ADF, which was low in GNS, the digestibility of nutrients was high in both rams and ewes. Among the three rations, nutrients digestibility was higher $(P<0.05)$ in the CPW group (rams and ewes), over the other two rations. However, SFH had almost the same level of the digestibility. The similarities between GNS and SFH rations could be due to the fact that they had almost the same level of fibre. The complete feed mash system used helped to improve the digestibility of the rations. The use of urea-N in the rations may also have contributed to the improvement in nutrients digestibility by the sheep (Loosli and McDonald, 1968).

The results of this trial demonstrated that sex has no influence on DMI, however, sex did influence nutrients digestibility and, subsequently, on the growth rate of sheep. 
TABLE 5

Effect of sex on apparent nutrients digestibility of complete mash rations by sheep

\begin{tabular}{|c|c|c|c|}
\hline \multirow{2}{*}{ Parameters } & \multicolumn{3}{|c|}{ Rations } \\
\hline & groundnut shells & sunflower heads & citrus pulp waste \\
\hline $\begin{array}{l}\text { Dry matter } \\
\text { ram lambs } \\
\text { ewe lambs } \\
\text { mean }\end{array}$ & $\begin{array}{l}79.4 \pm 0.38^{\mathrm{a}} \\
68.4 \pm 0.42^{\mathrm{b} 1} \\
73.9 \pm 0.40^{1}\end{array}$ & $\begin{array}{l}82.5 \pm 0.69^{\mathrm{a}} \\
77.0 \pm 0.38^{\mathrm{b} 12} \\
79.7 \pm 0.54^{2}\end{array}$ & $\begin{array}{l}82.1 \pm 0.49^{\mathrm{a}} \\
78.5 \pm 0.58^{\mathrm{b} 2} \\
80.2 \pm 0.54^{2}\end{array}$ \\
\hline $\begin{array}{l}\text { Crude protein } \\
\text { ram lambs } \\
\text { ewe lambs } \\
\text { mean }\end{array}$ & $\begin{array}{l}68.4 \pm 0.80^{1} \\
66.8 \pm 1.20^{1} \\
67.6 \pm 1.00^{1}\end{array}$ & $\begin{array}{l}72.5 \pm 0.58^{2} \\
70.6 \pm 0.98^{2} \\
71.6 \pm 0.78^{2}\end{array}$ & $\begin{array}{l}78.9 \pm 0.22^{3} \\
76.8 \pm 1.62^{3} \\
77.9 \pm 0.92^{3}\end{array}$ \\
\hline $\begin{array}{l}\text { NDF } \\
\text { ram lambs } \\
\text { ewe lambs } \\
\text { mean }\end{array}$ & $\begin{array}{l}74.6 \pm 0.98^{\mathrm{a} 1} \\
72.1 \pm 0.62^{\mathrm{b} 1} \\
73.4 \pm 0.80^{1}\end{array}$ & $\begin{array}{l}80.1 \pm 0.10^{\mathrm{a} 2} \\
78.1 \pm 0.08^{\mathrm{b} 2} \\
79.1 \pm 0.09^{2}\end{array}$ & $\begin{array}{l}81.0 \pm 0.93^{2} \\
79.1 \pm 0.72^{2} \\
80.0 \pm 0.83^{2}\end{array}$ \\
\hline $\begin{array}{l}\text { ADF } \\
\text { ram lambs } \\
\text { ewe lambs } \\
\text { mean }\end{array}$ & $\begin{array}{l}58.6 \pm 0.78^{\mathrm{a} 1} \\
53.9 \pm 0.72^{\mathrm{a} 1} \\
56.3 \pm 0.75^{1}\end{array}$ & $\begin{array}{l}67.1 \pm 0.80^{\mathrm{a} 2} \\
62.3 \pm 0.78^{\mathrm{b2}} \\
64.7 \pm 0.79^{2}\end{array}$ & $\begin{array}{l}78.0 \pm 0.42^{\mathrm{a} 3} \\
73.1 \pm 0.68^{\mathrm{h} 3} \\
75.6 \pm 0.55^{3}\end{array}$ \\
\hline $\begin{array}{l}\text { Hemicellulose } \\
\text { ram lambs } \\
\text { ewe lambs } \\
\text { mean }\end{array}$ & $\begin{array}{l}82.2 \pm 0.36^{\mathrm{a} 1} \\
80.1 \pm 0.18^{\mathrm{bl}} \\
81.1 \pm 0.27^{1}\end{array}$ & $\begin{array}{l}89.1 \pm 0.73^{\mathrm{a} 2} \\
82.7 \pm 0.69^{\mathrm{b} / 2} \\
85.8 \pm 0.71^{2}\end{array}$ & $\begin{array}{l}89.6 \pm 0.48^{\mathrm{a} 2} \\
87.3 \pm 0.92^{\mathrm{b} 2} \\
88.5 \pm 0.70^{3}\end{array}$ \\
\hline $\begin{array}{l}\text { Ccilulose } \\
\text { ram lambs } \\
\text { ewe lambs } \\
\text { mean }\end{array}$ & $\begin{array}{l}63.4 \pm 0.68^{\mathrm{al}} \\
58.9 \pm 0.94^{\mathrm{bl}} \\
61.1 \pm 0.81^{1}\end{array}$ & $\begin{array}{l}78.3 \pm 0.89^{\mathrm{a} 2} \\
75.7 \pm 0.86^{\mathrm{b} 2} \\
77.0 \pm 0.88^{2}\end{array}$ & $\begin{array}{l}79.7 \pm 0.96^{\mathrm{a} 2} \\
76.1 \pm 0.87^{\mathrm{b} 2} \\
77.9 \pm 0.92^{2}\end{array}$ \\
\hline $\begin{array}{l}\text { GE } \\
\text { ram lambs } \\
\text { ewe lambs } \\
\text { mean }\end{array}$ & $\begin{array}{l}79.4 \pm 0.92^{\mathrm{a} 1} \\
67.9 \pm 0.96^{\mathrm{b} 1} \\
73.6 \pm 0.94^{1}\end{array}$ & $\begin{array}{l}80.4 \pm 0.88^{\mathrm{a} 12} \\
78.2 \pm 0.58^{62} \\
79.3 \pm 0.73^{2}\end{array}$ & $\begin{array}{l}83.3 \pm 0.96^{\mathrm{a} 2} \\
80.4 \pm 0.82^{\mathrm{a} 2} \\
81.8 \pm 0.89^{3}\end{array}$ \\
\hline
\end{tabular}

a, b, c - means within each treatment for each variable of different superscript differ at $\mathrm{P}<0.05$ $1,2,3$ - means within row with different superseript differ at $\mathrm{P}<0.05$

Conclusively, the results demonstrated that complete feed mash can be prepared from locally available crop residues to produce cheap livestock feed, and it was also a means of improving the quality of residues for livestock nutrition in Zambia where they do not have enough feed resources to sustain high level of livestock production. 


\section{REFERENCES}

Abouheif M.A., Kraides M.S., Shatat R.A., 1992. Effect of docking and sex of lambs on carcass characteristics of the fat tailed Najdi sheep. J. Appl. Anim. Res. 1, 91-101

AOAC, 1980. Official Methods of Analysis. 13th Edition. Association of Official Agricultural Chemists, Washington, DC

Aregheore E.M., 1992. Crop residues in Gwembe valley goats rations. A contributed paper on Feed Resources for Goats. Vth International Conference on Goats, New Delhi, India, p. 10

Aregheore E.M., 1994a. Potential of crop residues in ruminant nutrition during the hot dry season in Zambia. Zambia J. Agric. Sci, 4, 39-42

Aregheore E.M., 1994b. Effect of sex on growth rate, voluntary intake and nutrient digestibility of West African Dwarf goats. Small Ruminant Res. 15, 217-221

Aregheore F.M., 1996. Voluntary intake and nutrient digestibility of crop residue based rations by goats and sheep. Small Rumant Res. 22, 7-12

Aregheore E.M., Chimwano A.M., 1991. Agro-industrial by products and crop residues in Zambia: Availability, utilization and potential value in ruminant nutrition. In J.E.S. Stares, A.N Said, J.A. Kategile (Editors), 1992. The complementarity of feed resources for animal production in Africa. Proceedings of the Joint Feed Resources Networks Workshop, Gaborone (Botswani). African Feeds Research Network. ILCA (International Livestock Centre for Africa), Addis Ababa (Ethiopia), pp. 223-238

Aregheore E.M., Tembo R., Lungu J.C.N., 1996. Utilization of complete rations based on crop residues by growing Blackhead shecp. (In press)

Cappock C. F., Noiler C.H., Wolfe S.A., 1974. Effect of forage concentrate ratio in complete feeds fed ad libitum on energy intake in relation to requirements by dairy cows. J. Dairy Sci. 57, 1371-1380

deHaan, 1991. Developments in Animal 'lechnology. In: 1. Garbus, A. Pritihard, O. Knudsen (Editors). Agricultural issues in the 1990s. Proceedings of the 11 th Agricultural Sector Symposium. The World Bank, Washington, DC, pp. 57-69

Gill J.L., 1978. Design and Analysis of Fxperiments. Vol. 1. Iowa State University Press, Ames, IO

Gocring H.K., Van Soest P.J., 1970. Forage Fibre Analysis, Apparatus, Reagents, Procedures and some Applications. Agric. Handbook 379, $\mathrm{R}$ R, USDA, Washington, DC, pp. 1-20

Ikhatua U.J., Dede T.I., Ototo M.E., 1991. The utilization of crop residues by West African Dwarf goats of Southern Nigeria. Nigcria Annals Nat. Sci. 1, 67-72

Kawalkar V.N., Patle B.R., 1978. Utilization of nutrients from complete rations by cross-bred (Holstein $x$ Tharparkar) lactating cows. Indian J. Anim. Sci. 48, 251-256

Krishnamohan D.V.G., Charyule E.K., 1983. Growth, nutrient utilization and carcass characteristics in lambs fed rations having different proportions of concentrate to roughage. Indian $\mathbf{J}$. Anim. Sci. 53, 1228-1232

Leng R.A., 1986. Drought Feeding Strategies, Theory and Practice. Penambal Books Armidale, Newsouth Wales, (Australia), pp. 1-139

Loosli J.K., McDonald I.W., 1968. Non-Protein Nitrogen in the Nutrition of Ruminants. FAO Agric Study, No. 75

Rakes A.H., 1969. Complete rations for dairy cattle. J. Dairy. Sci. 52, 870-875

Reddy M.R.. Reddy D.N., 1981. Complete rations for sheep, utilizing crop-residues and agroindustrial by products. Indian J. Anim. Sci, 51, 455-458

Reddy D.N., Reddy M.R., 1983. Effect of feeding complete rations on growth performance and nutricnt utilization in growing cross-bred calves. Indian J. Anim. Sci. 53, 697-700

Sharma V.V., Rajora N.K., 1977. Voluntary intake and nutrient digestibility of low-grade roughage by ruminatnis. J. Agric. Sci., Camb. 88, $75-78$ 
Shelton M., Carpenter Z.L., 1972. Influence of sex, stilbesterol treatment and slaughter weight on performance and carcass traits of slaughter lambs. J. Anim. Sci. 34, 203-207

Steel R.G.A., Torric J.H. 1980. Principles and Procedures of Statistics. 2nd Edition. McGraw Hill, New York, NY. 389 pp.

\section{STRESZCZENIE}

Wpływ płci owiec czarnogłówek na pobranie paszy, wzrost oraz strawność składników pokarmowych dawek pełnoporcjowych zawierających uboczne produkty roślinne

Na 10-cio micsięcznych 18 owcach czarnogłówkach ( 9 tryczków i 9 jarliczck) o początkowej masie ciala $16,9 \pm 0,59 \mathrm{~kg}$, oznaczono wartość pokarmową trzech pełnoporcjowych dawek (około $13 \%$ białka ogólnego) zawierających uboczne produkty roślinne: luski arachidowe (GNS), główki słonecznika (SFH) lub odpady pulpy cytrusowej (CPW), w układzie czynnikowym bloków losowych $2 \times 3$.

Płcć nie miala wpływu $(\mathrm{P}>0,05)$ na ilość pobieranej paszy, natomiast istotnic $(\mathrm{P}<0,05)$ wpływała na przyrosty dzienne i końcową masę ciała; lepsze wyniki miały tryczki.

Przyrosty jagniąl otrzymujących dawkę CWP były większe $(\mathrm{P}<0,05)$, zaś strawność i wykorzystanic paszy (kg SM/kg przyrostu) lepsze niż z pozostałych grup. 